\title{
Notas al pie de Gaza, de Joe Sacco: el anacronismo como posibilidad de acceso a la experiencia límite*
}

\author{
Juan Manuel Mancilla \\ U. Adolfo Ibáñez \\ dunalunar@gmail.com
}

\begin{abstract}
Resumen
Nos adentramos en las posibilidades de la novela gráfica como una plataforma discursiva de crítica social que reactualiza y tensa el otrora paradigma del arte comprometido. A partir de las ideas de Georges Didi-Huberman en Ante el tiempo, iremos desarrollando el análisis sobre la "modernidad del anacronismo", la funcionalidad de la "imagen-combate" y la efectividad de la "imagen-aura" en la propuesta de Joe Sacco. La problemática central del estudio se debate en la "lucha" entre palabra e imagen; esta última, en tanto dispositivo de acceso a la experiencia límite para reconstruir la memoria histórica del acontecimiento.
\end{abstract}

Palabras clave

Acontecimiento, memoria, novela gráfica, Sacco, Didi-Huberman

Joe Sacco's Footnotes in Gaza: Anachronism as a
Possibility of Access into Extreme Experiences

Abstract

This article explores the graphic novel as a discursive platform for social criticism that both renovates and questions the former paradigm of engaged art. Drawing on Georges Didi-Huberman's Before time, we will analyze the notion of "Modernity of Anachronism", the functionality of "confronting images", and the effectiveness of "aura images" in Sacco's proposal. The central issue of this study is debated in the "conflict" between word and image, considering the image a tool to access extreme experiences, in order to reconstruct the historical memory of events.

Keywords

Event, memory, graphic novel, Sacco, Didi-Huberman

* Recibido: 24 de agosto de 2016 / Aceptado: 3 de octubre de 2016. 


\title{
Notas sobre Gaza, de Joe Sacco: o anacronismo enquanto
} possibilidade de acesso à experiência-limite

\begin{abstract}
Resumo
Nós entramos nas possibilidades da novela gráfica enquanto plataforma discursiva da crítica social, que atualiza e tensiona o antigo paradigma da arte comprometida. A partir das ideias de Didi-Huberman apresentadas em Ante el tiempo, iremos desenvolver a análise da "modernidade do anacrônico", a função da "imagem-luta" e a efetividade da "imagem-aureola" na proposta de Sacco. A problemática central do estudo é uma luta entre palavra/imagem, esta última, enquanto dispositivo de acesso à experiêncialimite para reconstruir a memória histórica do acontecimento.
\end{abstract}

Palavras Chave

Acontecimento, memória, novela gráfica, Sacco, Didi-Huberman. 


\section{Introducción: literatura y arte en tiempos de incertidumbre}

A partir del desvanecimiento del paradigma idealista, en una era en que las formas y los esquemas tienden a descomponerse antes de alcanzar su grado de solidez o el estado de certidumbre que permita su proyección (Bauman, 2015), nos adentramos en las posibilidades de la novela gráfica como una plataforma discursiva de crítica social que reactiva y tensiona el otrora arte comprometido. Varios exponentes han incursionado en acontecimientos históricos de difícil comprensión, como es el caso del 11-S, a partir del cual Art Spiegelman publica Sin la sombra de las Torres (2004). Asimismo, la problemática de los enfrentamientos bélicos complejos ha sido abordada desde el lenguaje gráfico, como es el caso de la Guerra Civil Española en Malos tiempos, de Carlos Giménez (2007), de las matanzas étnicas en Bosnia oriental en Gorazde, de Joe Sacco (2012), o del conflicto Palestino-israelí en Palestina, del mismo autor (2004), y en Vals con Bashir, de Folman-Polonsky (2014).

En Notas a pie de Gaza, también de Joe Sacco (2012), nos encontramos tanto con el acontecimiento oscuro, un hecho de difícil comprensión que delimita un antes y un después, tal como lo es un enfrentamiento bélico, por lo cual entramos al texto preguntándonos lo siguiente: ¿Tiene la novela gráfica alguna injerencia como herramienta que construye un discurso de denuncia? ¿En qué medida las técnicas y recursos propios del género lo hacen apto para una crítica? Esto último, considerando que, desde sus orígenes, el cómic ha estado relacionado con la posibilidad de (ex)poner en escena contestatariamente las problemáticas sociales.

No es nuestro foco abordar la discusión sobre los aspectos que denominan al género, lo cual es en sí una línea particular de estudio (Barrero, 2013: 191, Campbell, 2013: 231), por lo que nuestra propuesta de lectura se adentra en comprender Notas al pie de Gaza como un texto que manifiesta una tensión en dos niveles discursivos disímiles de significación: uno verbal y otro visual. En el primero, se produce una aporía del conocimiento en relación al contenido de conciencia del testigo. Es decir, se expone la imposibilidad del narrador para detallar la esencia misma de la experiencia límite, así como el carácter específico del acontecimiento a través de los testimonios o de la documentación oficial disponible sobre el hecho. En el nivel visual, sin embargo, la oclusión es erosionada a partir de la imagen, permitiendo abrir el fenómeno en sí. La imagen, estímulo de la imaginación, posibilita graficar detalles que la verbalización deja difusos, borrosos o incompletos. A través de esta operación antitética, Sacco logra hacer hablar lo que permaneció en el silencio. Por lo tanto, la hipótesis que guía nuestro trabajo es que, frente a la retórica del discurso historicista, la imagen-combativa restaura del acontecimiento su imagen-aura desprendida del tiempo. 
Nos proponemos demostrar que, en Notas al pie de Gaza, la indecibilidad del acontecimiento histórico es consecuencia de la enunciación informativa. En este sentido, las imágenes gráficas logran acercarnos con actualidad y mayor sustancia al acontecimiento oscuro, recuperando, de lo "aquello", lo que era. Nuestro marco teórico se basa en las entradas que realiza Georges Didi-Huberman a las ideas de Walter Benjamin y Carl Einstein en su libro Ante el tiempo (2011), principalmente en la segunda parte, "Modernidad del anacronismo", y en los apartados "La imagen-combate" y "La imagen-aura". A través de estas nociones, iremos analizando y discutiendo la funcionalidad de las viñetas de Notas al pie de Gaza.

El presente trabajo se desarrolla en tres partes: primero, precisaremos algunos aspectos técnicos del lenguaje del cómic, para luego adentrarnos en la problematización central del texto a la luz de los conceptos de Didi-Huberman. Posteriormente, haremos una evaluación de la lectura propuesta y sus posibles alcances, intentando agregar perspectivas para la discusión respecto del lugar y el posible rol que le compete, hoy, al arte comprometido éticamente.

\section{Cuatro aspectos técnicos y formales relevantes de Notas al pie de Gaza}

En relación a los elementos compositivos específicos del lenguaje del cómic, hemos privilegiado cuatro para su comentario, apelando a la recurrencia de su empleo y a los efectos que provocan en la significación de la obra. Siguiendo las descripciones de Will Eisner (2007), estos recursos formales destacados, que retomaremos en la parte del análisis central de Notas al pie de Gaza, son: a) el uso de la viñeta como estrategia narrativa; b) la superviñeta como página; y c) la perspectiva; a los que añadiremos d) el claro/oscuro y el libro-objeto en tanto agregados performativos. A continuación, describimos y comentamos su uso en la obra de Joe Sacco.

\section{a) El uso de la viñeta como estrategia narrativa}

En cuanto al uso de la viñeta como estrategia narrativa en Notas al pie de Gaza, éstas son un soporte empleado en donde se insertan los cartuchos a modo de "notas". Esta forma estratégica da cuenta de la conciencia metatextual en la concreción formal de la obra. En el "Prólogo" de la novela gráfica, se indica que un hecho particular habría sido minimizado por organismos oficiales como la ONU o el gobierno de Israel, aludiendo a una "revuelta" de palestinos en el contexto de La Guerra del Sinaí. Recordemos que este conflicto militar implicó la alianza militar formada por el Reino Unido, Francia e Israel contra Egipto para tomar posesión del Canal de Suez:

Por alguna razón, los responsables de la revista (Harpers) eliminaron aquella sección (la masacre de Khan Younis en 1956) ... Ese episodio... no merecía ser relegado al 
olvido de ese modo. Pero allí quedaba, al igual que otras tragedias históricas que a través de los tiempos apenas alcanzan categoría de nota a pie de página en el amplio barrido de la Historia... (Sacco, 2012: IX).

Vemos que las "notas" y sus mensajes están superpuestos y pegados sobre las páginas-viñetas figurando los Post it, adhesivos cuya finalidad es una ayuda memoria y recordatorio para la vida cotidiana. En la secuencia, su "papel" en relación a la funcionalidad narrativa es muy relevante, porque traman y entregan el punto de vista del narrador protagonista del relato, el personaje Joe Sacco.

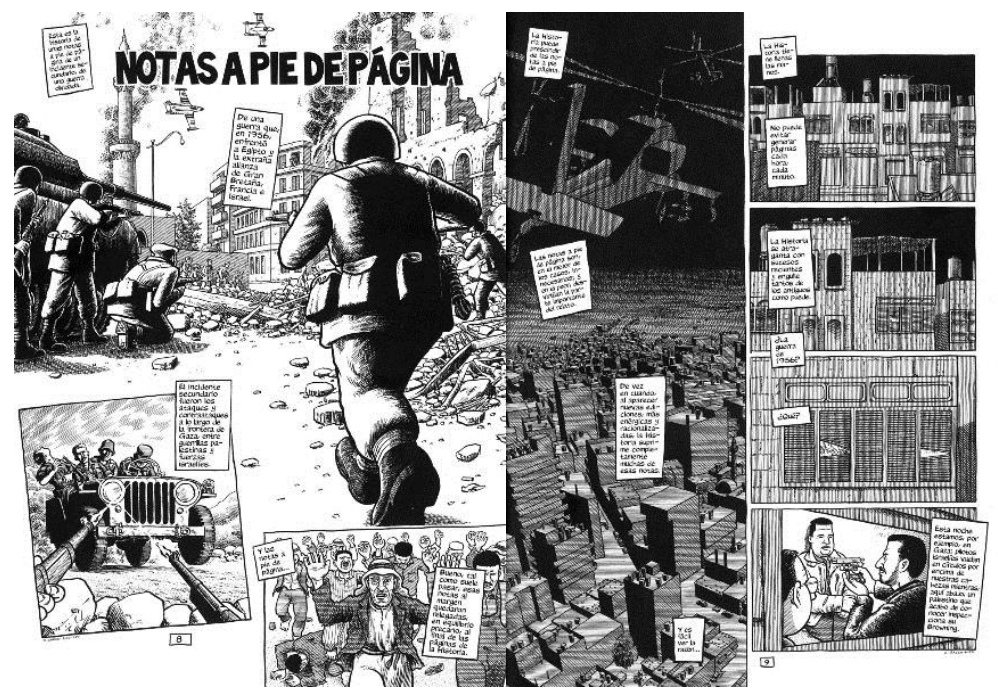

Ilustración 1 (Sacco, 2012: 8-9).

En el primer cartucho leemos: "Esta es la historia de unas notas a pie de página de un incidente secundario, una guerra olvidada" (Sacco, 2012: 8). La cuarta nota nos adentra en la problemática teórica que enfrenta la obra: "Bueno, tal como suele pasar, esas notas al margen quedaron relegadas, en equilibrio precario, al final de las páginas de la Historia". Las referencias metatextuales en relación al soporte-contenido de las "notas" y a la "Historia" con mayúscula, son los ejes articuladores centrales que apuntan la crítica al poder oficial versus las experiencias del saber excluido y marginado, en este caso, las "pequeñas" historias olvidadas de los habitantes de Gaza.

En relación con el uso técnico de este recurso, Eisner plantea:

El propósito de la viñeta es, más que ofrecer un escenario, involucrar al lector en la narración. En tanto que la viñeta cuadrada y convencional mantiene a raya al lector -o fuera de la viñeta por así decirlo- los marcos [...] invitan al lector a participar en 
la acción o hacen que la acción "estalle" hacia el lector [...]. [Este tipo de viñeta] se esfuerza por alcanzar otras dimensiones sensitivas (2007: 48).

En este sentido, Sacco logra la maximización del significado con una mínima utilización de elementos, particularmente en la forma de condensar la materiaproblema. De esta manera, provoca la apertura del "gran" asunto que suscita su novela gráfica, es decir, el de las problemáticas que supone el proceso de reconstruir, a través de la memoria, una relación de hechos cuyas características los enmarcarían dentro de los límites de un acontecimiento de difícil acceso, con el consiguiente trauma del sujeto superviviente (LaCapra, 2006). Sacco pretende recuperar los detalles de dos matanzas ocurridas en 1956, tras la retirada de las tropas israelíes del territorio en Khan Younis y Rafah, dos campos-ciudades de Palestina.

En la página siguiente, leemos: "La historia puede prescindir de las notas a pie de página... son, en el mejor de los casos innecesarias; y en el peor, desvirtúan la parte importante del relato". Vemos que las primeras citas ironizan las referencias a la Historia con mayúscula, esa historia que "tiene las manos llenas [...] que no puede evitar de generar páginas a cada minuto [...] la Historia que se atraganta y engulle [...] ¿La guerra de 1956?" (Sacco, 2012: 9).

En la viñeta, un helicóptero patrulla la ciudad mientras las notas caen desde el cielo, hasta que el narrador transcribe directamente sobre ellas el diálogo de los tres actores principales de Notas al pie de Gaza: Abed, contacto de enlace con los testigos palestinos; Khaled, un "Mutarad" fugitivo y "héroe" de las intifadas; y Joe Sacco, periodista maltés-americano que quiere reconstruir los acontecimientos de 1956.

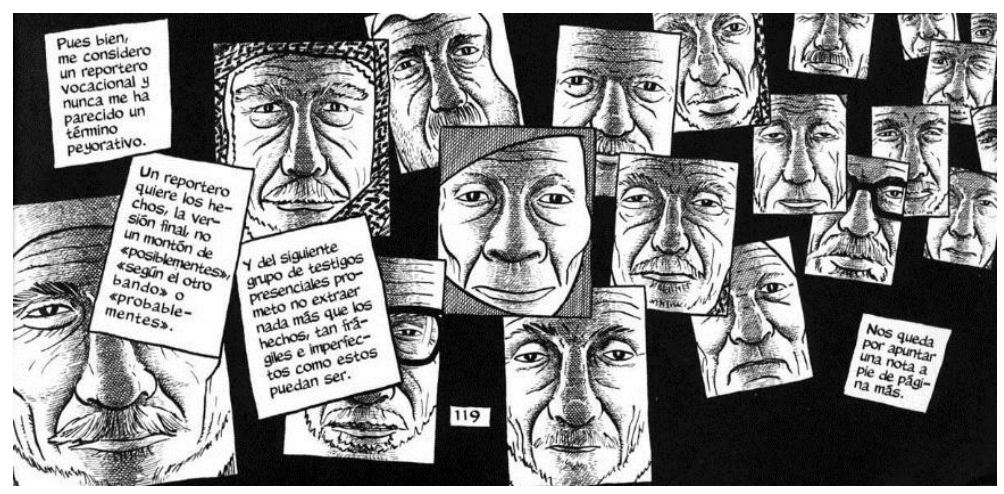

Ilustración 2 (Sacco, 2012: 119).

En la última viñeta de "Khan Younis", primera parte de la novela gráfica, también observamos el empleo estratégico de ella en tanto instancia narrativa, 
pues las "notas" verbales se mimetizan con las notas-rostros de los testigos. No obstante, el mensaje de los textos proporciona una conclusión valorativa negativa. Desaprueba la relación de funcionalidad en la metodología investigativa que fue llevada a cabo en la pesquisa periodística. La operatividad de Sacco como "notero" de prensa queda cuestionada: "Un reportero quiere los hechos, la versión final, no un montón de 'posiblementes', 'según el otro bando', 'probablementes'... Nos queda apuntar una nota a pie de página más" (Sacco, 2014: 119). Es decir, cada persona es una nota a pie de página, cada sujeto es una historia particular imposible de desentramar.

\section{b) La superviñeta como página}

Siguiendo a Eisner, "cuando la superviñeta representa ser una página [...] funciona como contenedor sin marco. Y donde se emplea mejor es en las narraciones paralelas" (2007: 82). La definición resulta de interés para el análisis del recurso en el texto, ya que es uno de los componentes estructurantes más significativos de la novela gráfica de Sacco. En la obra, el paralelismo narrativo es una constante y esto se manifiesta en que la misma novela está divida en dos, puesto que las acciones principales del relato se concretan en dos locaciones, a saber, las ciudades-campo de Kahn Younis y de Rafah. El esquema temporal se mueve en dos temporalidades, el pasado y el presente. También son dos las líneas narrativas, la del narrador protagonista y la de los testigos.

Vistas estas características de la estructura dual del texto, advertimos cómo funcionan a nivel interno, cuyo ejemplo lo acotamos en la siguiente superviñeta (Imagen 3). Podemos señalar el funcionamiento de la estrategia de narrar en forma paralela, pues la viñeta de la izquierda nos lleva al pasado, exactamente, al 3 de noviembre de 1956, día de la matanza frente al Castillo Mamluk, en Kahn Younis. En ella, un niño de espaldas contempla estupefacto la matanza, mientras en la siguiente, a través de una elisión, se da un salto en el tiempo que transporta al presente de automóviles aparcados y personas que recorren el lugar, el ahora, el hoy como si ahí nada hubiera ocurrido. En el ángulo inferior derecho, vemos a Joe, Abed y Faris Barbakh; este último, el testigo que relata los hechos acaecidos aquella mañana de 1956.

En la siguiente página opera el mismo procedimiento, pero acotado a una viñeta en la que el flash back temporal bien podría representar un zoom a la historia personal del presente de Faris. En efecto, se le muestra ante al muro y observando el recuerdo a través de lo invisible de aquella mañana trágica, con la paradójica visión vacía del fondo ahora "construida" frente al presente. 


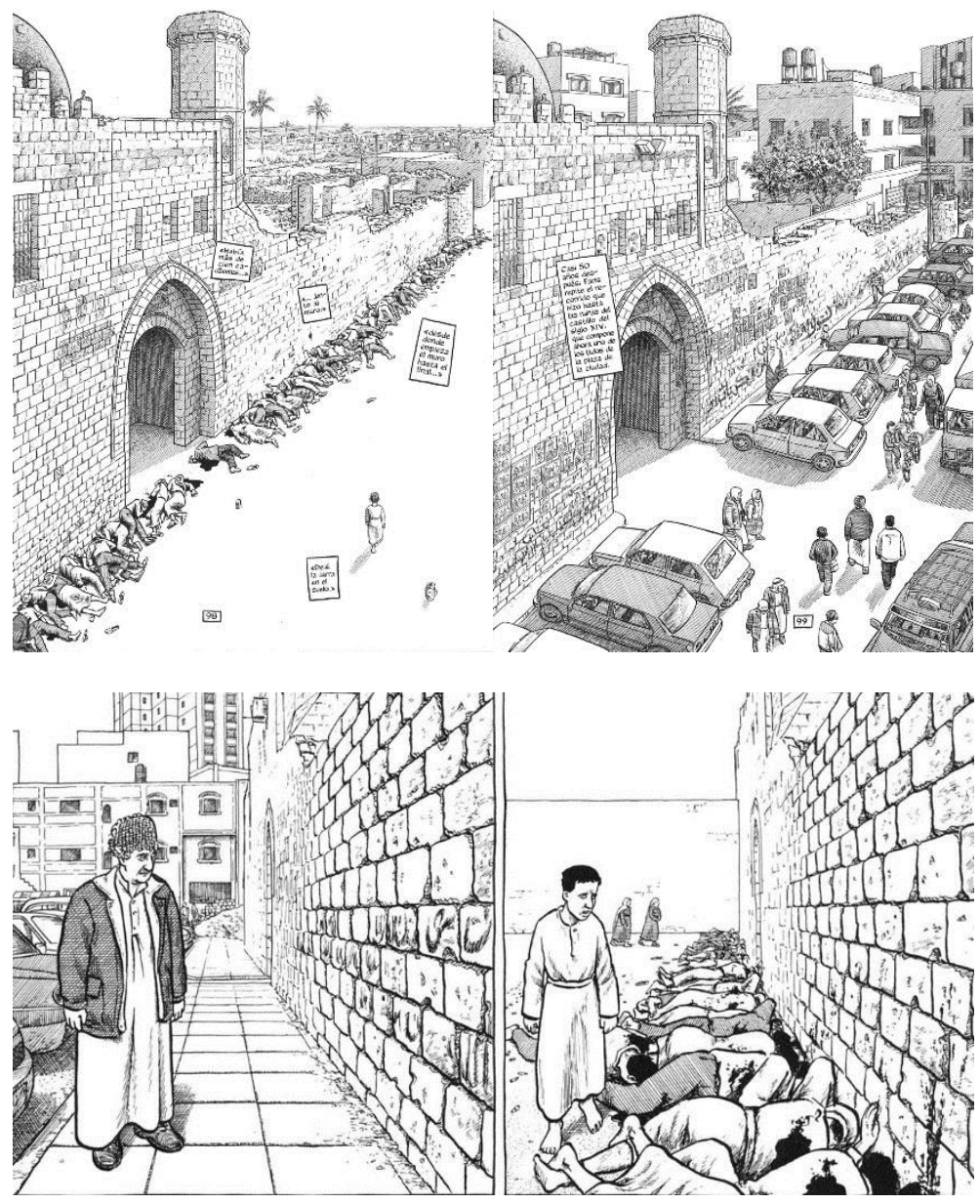

Ilustraciones 3 y 4 (Sacco, 2012: 98-99 y 100).

\section{Citando a Eisner:}

Dado que las escenas de acción y otros acontecimientos no tienen por qué distribuirse uniformemente, algunas páginas deberán contener más escenas individuales que otras. Conviene tener en cuenta que cuando el lector pasa una página, se produce una pausa. Esto permite un cambio de tiempo, un salto de escenario, una oportunidad para controlar la atención del lector [...] se juega tanto con la retención como con la atención [...] (2007: 65).

En este sentido, cada página se ofrece con una duración específica de lectura, como una forma de adjudicarle tiempo extra al texto y de someternos a un ritmo desigual respecto de las anteriores. Con las alternaciones temporales y espaciales, 
el proceso lector enfrenta un quiebre, una partición, símil y contrapunto de lo que ocurre a nivel intradiegético. Agregaríamos que la reiterada inclusión de elisiones temporales abrocha historias distantes, mientras que los montajes urden una manera de re-unir dos distancias en la que el arte (la novela gráfica) reataría nudos cortados. De esta manera, la superviñeta se presenta como una totalidad que, en el despliegue, permite la imbricación del tiempo-espacio perdido en la infinitud del olvido. A propósito:

Los hechos de 1956 se funden con la actualidad de Gaza, donde cada día un nuevo episodio de violencia jalona la historia. Esa es la crítica que Sacco escucha de los más jóvenes - ¿a quién le interesa qué ocurrió hace 60 años, teniendo en cuenta lo que pasa ahora?-y la que puede constatar durante su estancia, aún durante la ocupación israelí. Casas demolidas por excavadoras israelíes, tiroteos y 'asesinatos selectivos' israelíes se entremezclan con el relato histórico, demostrando que, en todo este tiempo, las cosas no han cambiado tanto en tierras palestinas. Su cotidianidad sigue siendo la guerra, y gracias a la indiferencia mundial, su drama sigue constituyendo una anotación al pie de página de la Historia (Prieto, 2016).

El uso de la superviñeta está reservado casi exclusivamente para aquellos momentos en los que el contenido de la narración acelera el ritmo para acercarse al clímax, que, en este caso, coincide con las dos matanzas. Es ahí donde el recurso cobra sus máximos efectos, dado que cumple con su propósito de alternar y fusionar en simultáneo dos eras, dos épocas, dos hechos que, distando en el tiempo-espacio, son susceptibles de reconstruirse a través del procedimiento retórico-técnico, en cuyo uso artístico proponemos un fin último, una posible ética artística contemporánea.

\section{c) La perspectiva}

Una de las funciones principales de la perspectiva en el cómic es la de dirigir la mirada del lector y, con ello, "guiar" su percepción respecto de lo que es objeto de su atención, proporcionando la capacidad de poder moverlo, situarlo y conducirlo hacia donde el narrador quiere Ilevarle. Este último proyecta y configura la dinámica del relato en relación al punto de vista en la experiencia lectora, pasando de una posición de distancia/cercanía hasta situarse fuera/dentro o abajo/arriba de las acciones. Este aspecto es fundamental para construir el sentido implícito del texto, ya que el lector irá urdiendo la trama de acuerdo al punto clave que el narrador propone y dirige. Al respecto, Eisner agrega que "la forma de la viñeta combinada con la perspectiva fomenta esas reacciones como respuesta al entorno. Una viñeta estrecha hace sentirse encerrado, mientras que una viñeta amplia sugiere un espacio ancho en el que moverse o escapar" (2007: 91). 
A nivel literario, esto puede vincularse con el concepto de focalización, entendido como "las relaciones entre los elementos presentados y la concepción a través de la cual se presentan. La focalización será, por lo tanto, la relación entre la visión y lo que se 've', lo que se percibe” (Bal, 1990: 108). Así, en la focalización, la forma y la manera en que se van proponiendo y desarrollando las acciones es indirectamente proporcional al contenido y la forma de la significación. En relación a este punto específico de Notas al pie de Gaza, planteamos que los enfoques y perspectivas están dispuestos para alcanzar la integración del lector e involucrarlo en los hechos. Las imágenes propuestas apelan (exhortan) a que nos mantengamos en contacto directo con las acciones. De este modo, la función fática juega un rol preponderante, a través del uso de determinadas perspectivas que construyen su composición icónica.
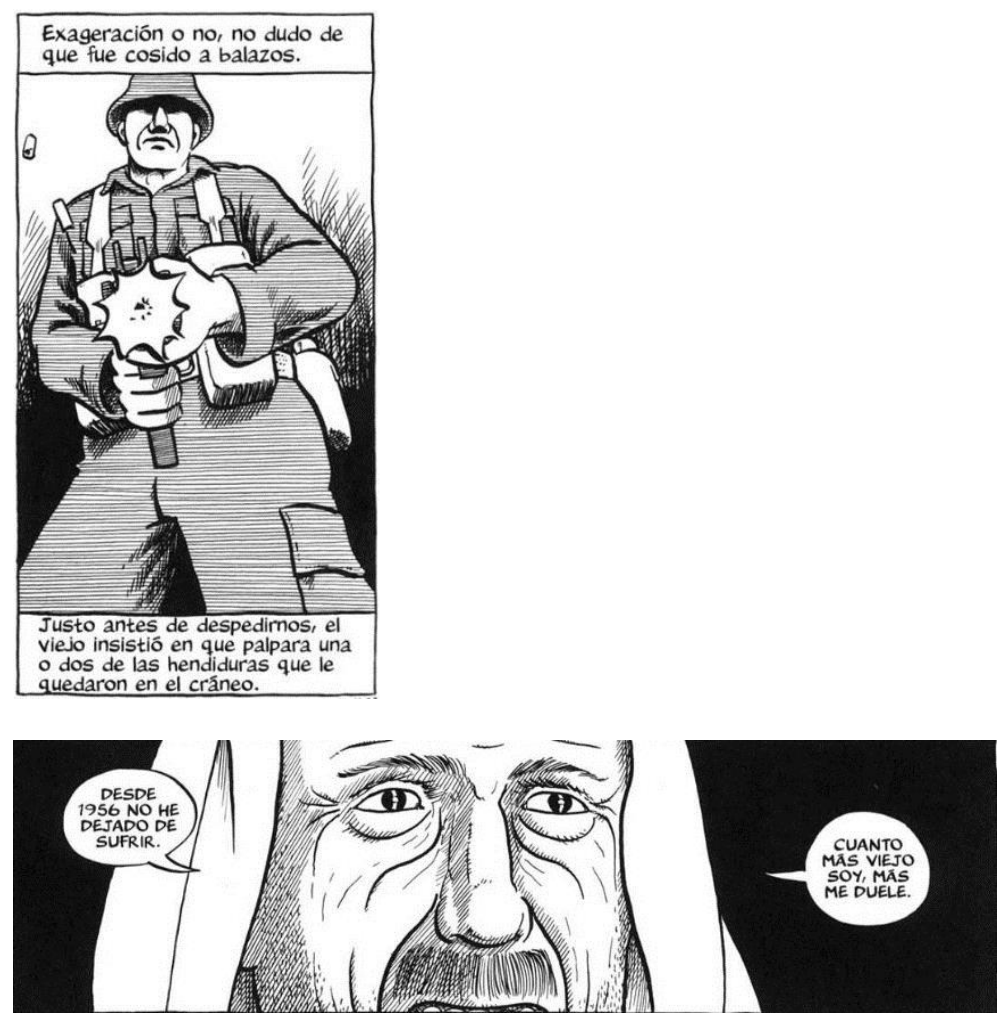

Ilustraciones 5 y 6 (Sacco, 2012: 224).

Los ángulos escogidos nos "enfrentan" a las situaciones, nos acercan hasta ser uno más de ellos (los personajes), pero también nos alejan, ya que la figura misma 
de Sacco está en ese tránsito de ir / venir, acercar / alejar(se) del conflicto. Y esto lo juzgamos positivo, pues nos enfrenta como lectores a la disyuntiva, al pleno ejercicio de la reflexión, a su constante movimiento; lo cual, si fuera su contrario, se tornaría inmóvil y accesorio. En cambio, estos giros y movimientos de perspectiva producen una dinámica activa de relaciones frente a los hechos y sus protagonistas. Son múltiples los ejemplos sobre las perspectivas concretadas en la novela gráfica, no obstante, citamos los siguientes, con la intención de refrendar lo que venimos proponiendo.
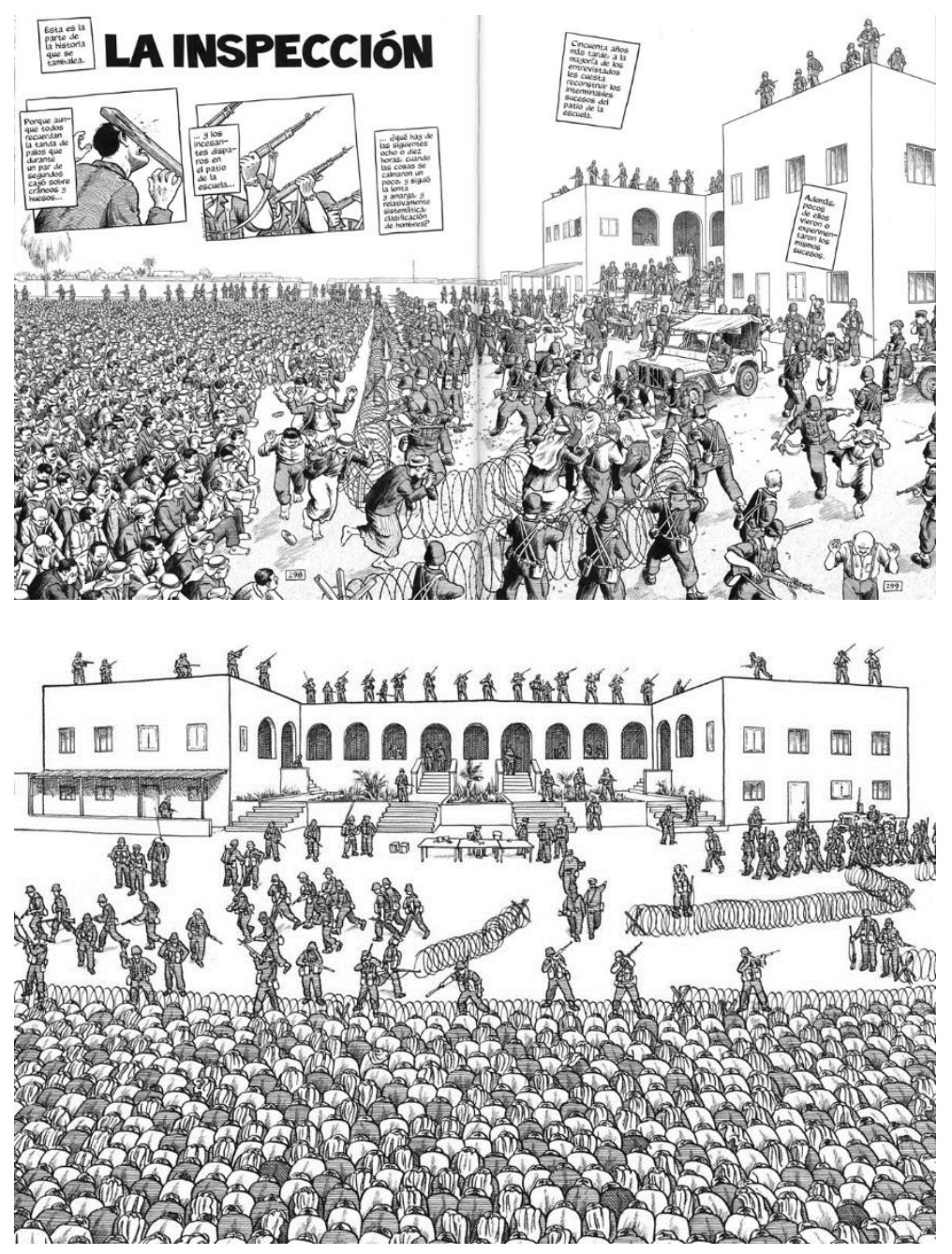

Ilustraciones 7 y 8 (Sacco, 2012: 268 y 298-299). 
En las viñetas del capítulo "La inspección", destacamos la significativa posición en la cual nos aposta el narrador, por cuanto nos brinda una visión panorámica del lugar, los hechos y la toma de posición a la que nos desafía. Estamos situados / sitiados frente a los soldados israelíes, quienes apuntan con sus ametralladoras. Logramos observar a los prisioneros palestinos por debajo de nuestra mirada, agachados en posición de tortura, con la cabeza doblada y la vista hacia el suelo, al contrario del lector-espectador que observa asumiendo el rol de testigo del suceso. Sin embargo, también estamos del lado de acá y bajo los soldados israelíes que se ubican en la azotea del edificio de la escuela por sobre nuestra cabeza. De alguna manera, somos blanco de aquellos soldados.

Esta perspectiva dinámica focalizadora posibilita tomar distintas posiciones para enfrentar el relato. En otras ocasiones nos sitúa por sobre los hechos, desde arriba o desde el aire, pero no con las cualidades de la omnisciencia, sino en tanto testigos y también responsables del horror de la devastación bélica.

\section{d) El claro/oscuro y el libro-objeto en tanto agregados performativos en No- tas al pie de Gaza}

Como ya hemos dicho, uno de los ejes compositivos en Notas a pie de Gaza es la dualidad, expresada en múltiples concretizaciones tanto en el plano del significante como en el del significado. La clave del doble impar, es decir, una imagen espejo que permite producir una dialéctica de fórmulas binarias y antitéticas tales como las de ellos / nosotros, arriba / abajo, malos / buenos, adentro / afuera, pequeño / grande, pasado / presente y, entre ellas, la de claro / oscuro, de manera destacada.

La cromática por la cual Sacco opta en Notas al pie de Gaza, al igual que en Palestina en la Franja de Gaza, es la del blanco / negro (a excepción de la portada de la edición donde el título está en rojo), cuyo efecto es siempre el del contraste entre luz y sombra por donde se desenvuelven los personajes de la novela. No hay espacio para la inclusión de otras tonalidades. Gaza es en extremos; no hay término medio en el conflicto de Medio Oriente, no hay posibilidad de una alternancia.

El acontecimiento narrado es en sí "oscuro", de difícil o imposible acceso, como un abismo, incluso, impenetrable. De igual manera, el trazo que predomina en las viñetas logra semejanza con el de los grabados, en particular con los de Gustavo Doré, precisamente en sus ilustraciones de libros y novelas de caballerías. También vemos los intertextos cromáticos posibles con el Guernica de Pablo Picasso, cuyo referente extratextual es un acontecimiento bélico. 

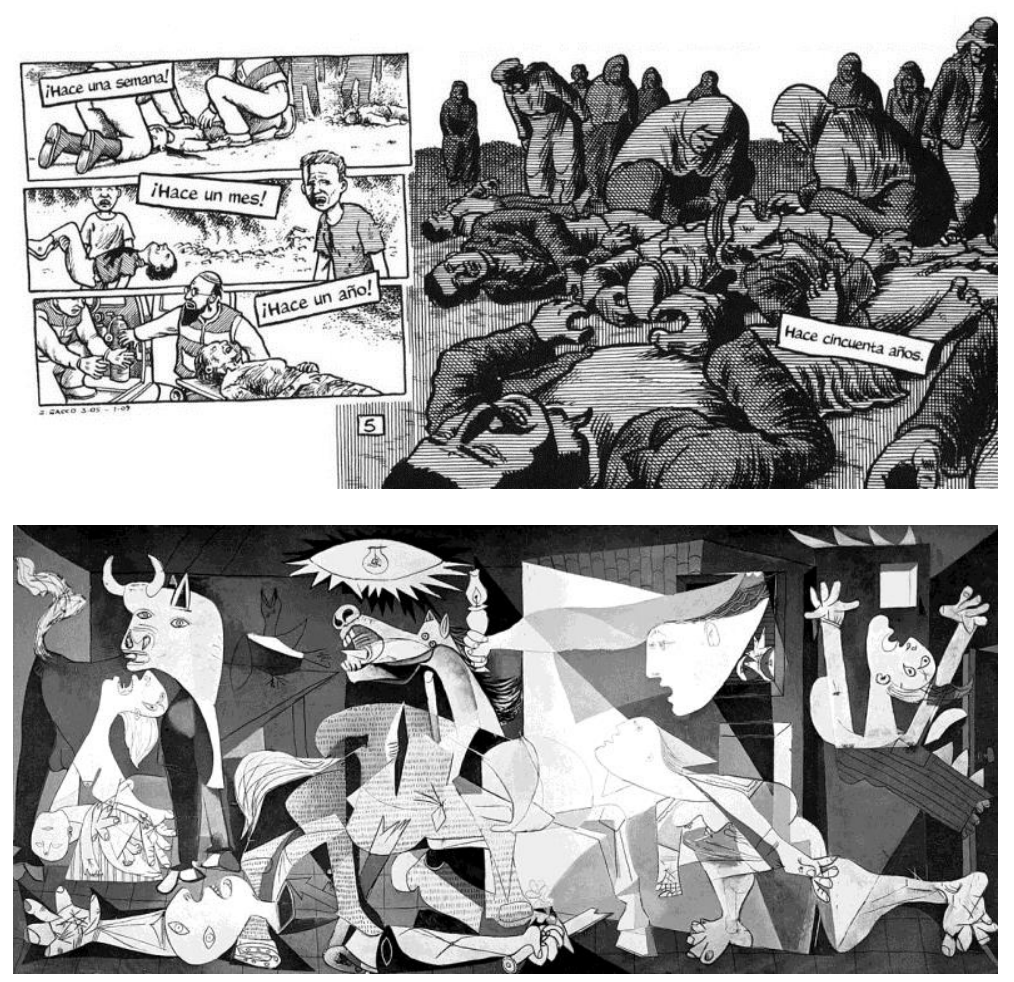

Ilustraciones 9 (Sacco, 2012: 5) y 10 (Picasso, 1937: Guernica).

Por otra parte, el libro como objeto efectivamente dota de un peso específico a algo a lo cual se le había restado su valor: un libro pesado, grande, de gruesa densidad, cuyo volumen amplifica la voz de los testigos, la de los testimonios recogidos. Existe una ostensible decisión de "hacer notar" y evidenciar lo que, para la Historia oficial, no es más que una documentación burocrática de rendición de cuentas, en lo que cabe a muertos por conflicto. En este sentido, la hoja, su textura gruesa, la cantidad de páginas y de paratextos asignados para las dos matanzas, conforman a Notas al pie de Gaza como un gran objeto que no puede ser invisible, que no puede ser inadvertido, y adquieren valor agregado en relación al tamaño, volumen y peso de las experiencias contenidas en la obra. Citando las ideas de Eisner sobre este tipo de viñeta donde el autor "se esfuerza por alcanzar otras dimensiones sensitivas" (2007: 48), esta es una forma más de concretar una obra performativa, pues constantemente está apelando al lector, llamándolo a participar directamente, a involucrarse, a ser un testigo más, uno que pueda dar fe de los hechos, específicamente, de las matanzas de Kahn Younis y Rafah. 
Finalmente, el realismo con que Sacco trata los hechos en cuanto a descriptores del contexto, suponemos, intenta dar cuenta del detalle desde su perspectiva profesional, como periodista que desea reconstruir lo más fielmente posible el "lugar de los hechos". De ahí la minuciosidad del fragmento, del trazo mínimo que grafica un tiempo de detención necesario para la percepción del detalle.

\section{Análisis: la imagen frente a la imposibilidad del decir la Historia}

Uno de los problemas a los cuales nos enfrenta la novela Notas al pie de Gaza es la manera en que problematiza la historiografía, puesto que uno de sus argumentos principales es el desplazamiento y marginación de acontecimientos complejos que la Historia oficial no integra, obliterando sus detalles, descartándolos sin más justificación que la sellada en la documentación archivística oficializada sobre las masacres de 1956.

Esta formalización y "legitimación" de hechos resta de ellos su cualidad de acontecimiento límite, como define LaCapra a "aquel que supera la capacidad imaginativa de concebirlo o anticiparlo", de modo que "antes que ocurriera no fue -acaso no puede serlo- previsto ni imaginado" (2006: 181). Tal sucede en el caso de Notas al pie de Gaza, en donde Sacco (autor real) inicia la investigación de un asunto "olvidado", a partir de unas notas a pie encontradas lateralmente. No obstante, nos adentraremos privilegiando primeramente otra vía de entrada al texto, la cual también nos hará llegar a la problemática historiográfica planteada de forma y de fondo en esta novela gráfica.

En Notas al pie de Gaza, el impedimento al acceso y la dificultad de entrar en la zona oscura del acontecimiento radica en la pretensión del narrador protagonista de "hacer" de los testimonios información y de transformarlos indefectiblemente en historiografía al traducirlos. No son escasos los episodios en los cuales encontramos al personaje periodista alter ego de Joe Sacco preocupado en relación a su propósito profesional de reconstruir la masacre de 1956 en Kahn Younis y Rafah. En ocasiones, se nos muestra en una actitud voraz e intrépida de perseguir sus objetivos poniendo en tela juicio los protocolos de la cortesía. En otras secuencias, se nos muestra frustrado ante la imposibilidad de "armar" el puzle testimonial de manera objetiva y precisa. Por ejemplo, en el capítulo "Los Fedayín", Sacco y Abed entrevistan y descartan "hombres" a fin de obtener información "válida", en una visita rutinaria a Kahn Younis. En el texto leemos:

...y ya la primera mirada nos dice que este es nuestro hombre", "Este es nuestro hombre y aquí mi grabadora...", "... y con el último saludo de las obligadas cortesías de rigor aún en el aire, suelto la primera pregunta. Entonces..."

No, no quiere hablar aún de ello... ¡Por Dios! ¡Estamos en Ramadán y el sol no se ha puesto aún! 
Y así empieza el exasperante y desigual combate que enfrenta al desventurado dibujante de cómics y el ladino ex-guerrillero... (Sacco, 2012: 41).

Más adelante, en otro fragmento, un episodio similar en Rafah:

Nos reunimos en un despacho con Abed y yo [,] intercambiamos miradas de inminente triunfo periodístico... Estamos a punto de hablar con un hombre que estuvo allí, recogiendo los cuerpos. ¡Todo encaja!

Ibrahim Saker empieza a hablar y nuestro sueño se derrumba. El incidente es de 1967, no 1956... Ibrahim nos cuenta que los cuerpos quedaron allí por veinte días... él fue uno de los enviados [para recogerlos] "pero no me pude queda por el olor".

Nosotros tampoco nos podemos quedar. Hemos perdido interés. 1967 no es nuestro departamento (Sacco, 2012: 338).

Podemos observar la actitud ambiciosa de Sacco (personaje), a quien no le importan ni los códigos culturales ni las tradiciones, ni tampoco se da cuenta o bien le resta relevancia a la posibilidad de destapar otras masacres. Lo que prima son sus metas revestidas de un pragmatismo laboral impostergable. Su "misión" personal es la prioridad total de sus afanes.

Advertimos que, en el proyecto del personaje Sacco, predomina la idea de construir un texto periodístico, un relato que se transforme en fuente informativa veraz, citable y objetiva; un dato que se constituya en documento con propiedad histórica. Sin embargo, es ahí donde, precisamente, radica su debilidad, su falla (programada): en pretender dar cuenta a través de una forma de discursividad presuntamente objetiva los detalles indefinidos de la experiencia límite. Un deseo frustrado por medio de la informatividad del texto periodístico, que, dada su solidez transparente, está impedido de filtrarse en las fisuras del acontecimiento.

En ciertas secuencias, se nos muestra al personaje pragmático y metódico que pone toda la fe en que, mediante una metodología científica de trabajo, logrará reconstruir las masacres que pesquisa. Sacco (ficcional) experimenta la frustración por la dificultad de no poder sortear los obstáculos de la reconstrucción desde la objetividad periodística. O también se nos muestra en la entusiasta ambición que se quiebra ante los límites del estatuto ontológico e instrumental del lenguaje objetivo, ya sea el del periodismo o el de la documentación historiográfica, puesto que igualmente fracasa en su intención reconstructiva integral y sistémica. En este sentido, son ejemplares los capítulos "La memoria y la verdad esencial" y "Documento", ya que en ellos podemos advertir esta incapacidad del poder decir a través de esta vía pragmática y teleológica del lenguaje pre-programado. Por ejemplo, los cartuchos-notas dicen lo siguiente en el primero de los capítulos citados:

Acabáis de leer una serie de recuerdos personales que cuentan la historia de cómo, en Khan Younis, el 3 de noviembre de 1956, soldados israelíes consumaron grandes matan- 
zas de palestinos [...] Permítanme ahora que socave los pilares en que basa nuestra historia [...] No falta decir que los recuerdos cambian con los años, y los que aquí hemos removido son viejos de varias décadas [...] La memoria desdibuja los contornos: añade y sustrae [...] (Sacco, 2012: 112; cursiva nuestra).

Es significativo este capítulo, por cuanto realiza una evaluación y un repaso autoevaluativo del trabajo hecho. Además, efectúa una especie de puesta en duda, una reflexión metatextual y metadiscursiva sobre el contenido de los testimonios recopilados. El narrador cita el caso de Omm Nafez y Khamis para demostrar la labilidad de los testimonios, cuestionando la veracidad de los mismos.

A continuación, el capítulo "Documento" viene a poner otra disyuntiva en cuanto a la parte oficial, redactada por las fuentes y organismos ad hoc en relación a los hechos, citando la versión de la ONU sobre lo ocurrido en Khan Younis. En tales documentos, en efecto, se da espacio y voz a los testigos privilegiados del otro lado, es decir, a los soldados israelíes, entre los cuales Sacco de igual manera se encuentra con diferentes versiones sobre lo ocurrido, poniendo entre paréntesis interrogativos la posibilidad de llegar al centro del límite vía discurso oficial.
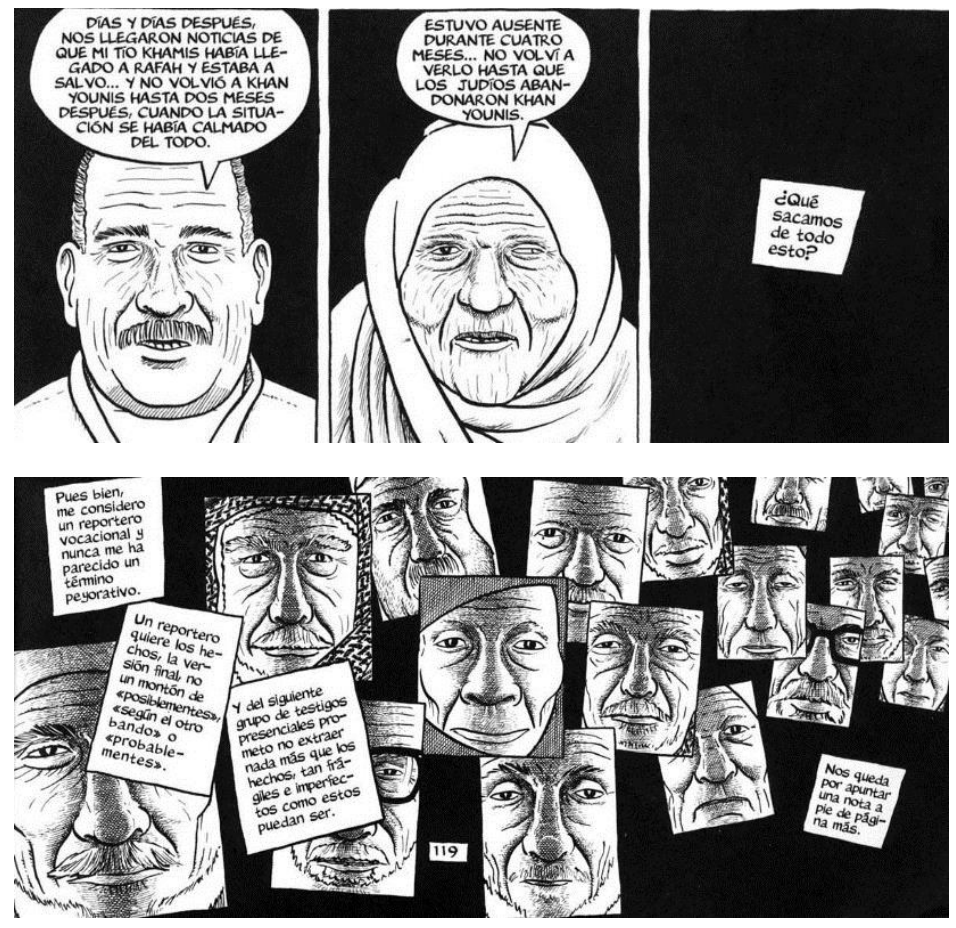

Ilustraciones 11 y 12 (Sacco, 2012: 115 y 119). 
Al respecto, son de interés las apreciaciones de Díaz de Guereñu (2014: 59102) en relación al cómic de guerra y su función de testimonio. También es esclarecedor el trabajo de Daniel Worden (2015), quien aborda las implicancias entre cómic, realidad y periodismo. De todas maneras, como hemos sostenido, en la novela gráfica de Sacco existe una relación imposible entre el informar la historia y el visualizar la memoria, entendiendo que esta última tiene la capacidad de hacer frente al fracaso de la retórica informática en el deseo de llegar a la verdad última. La imagen, aunque sea la del vacío y la oscuridad, se torna una posibilidad que restaura del acontecimiento impenetrable el aura desapercibida para la Historia. Sore esto, se señala lo siguiente:

Frente la querencia por la frialdad de los hechos convertidos en palabras desnudas de todo sentimiento en pro de la pretendida objetividad de la prensa tradicional, los escritores del Nuevo Periodismo dan un vuelco a la norma: considerar al periodismo como fuente de objetividad es un error de grado. Si en torno a la naturaleza de la Historia, Hayden White (1992) estableció que los hechos, una vez convertidos en discurso no equivalen a verdad pues existe un proceso de interpretación a través de un punto de vista determinado; los nuevos periodistas, aun operando con una base real emplean elementos propios de la literatura en sus obras sin por ello perder un ápice de honestidad: yo estaba allí y esta es solo mi visión. "En última instancia -escribe Sacco en Reportajes-, un dibujo refleja la visión de cada dibujante individual", pero no por ello deja de ser veraz y fiel a una realidad determinada [...] (Barros, 2016).

Las imágenes que acompañan a la verbalización adquieren otra dirección, que, precisamente, podría calar en la opacidad del acontecimiento y tendría la capacidad de hacerlo narrar y no informar. Así, el relato de los testigos adquiriría otra dimensión, se inscribiría en otra temporalidad, en la cual habría un significado grabado, impreso, impregnado e indeleble. En este sentido, es preciso lo propuesto por White:

¿Qué implica, pues, ese hallar el "verdadero relato", ese descubrir la "historia real" que subyace o está detrás de los acontecimientos que nos llegan en la caótica forma de los "registros históricos"? ¿Qué anhelo se expresa, qué deseo se gratifica por la fantasía de que los acontecimientos reales se representan de forma adecuada cuando se representan con la coherencia formal de una narración? En el enigma de este anhelo, este deseo, se vislumbra la función del discurso narrativizador en general, una clave del impulso psicológico subyacente a la necesidad aparentemente universal no sólo de narrar sino de dar a los acontecimientos un aspecto de narratividad (1992: 20).

Ante estas interrogantes planteadas por White, proponemos que las respuestas están en el plano discursivo que conforman las imágenes de Notas al pie de Gaza. Retomando las palabras irónicas de Sacco personaje, "la memoria desdibuja los contornos: añade y sustrae". Entendemos que precisamente ahí, en el contorno difuso, la imagen dibujada produce el "hallar el verdadero relato". La imagen con-tiene lo que la palabra con-torna confuso. Ahí donde las palabras funcionalizadas, teleologizadas acaban mudando, las imágenes se abren y testimonian en y desde el otro lado, desde el centro 
de lo impenetrable, con otra percepción del espacio y del tiempo. En un estudio de Jaume Peris, encontramos una idea semejante sobre el caso de los campos de concentración chilenos y la experiencia límite de Hernán Valdés, en tanto testigo y superviviente de un acontecimiento: "Si algo define a aquellos que han logrado sobrevivir es, en primera instancia, su silencio con respecto a lo vivido en su interior y, sobre todo, la imposibilidad de articular en forma de narración algo del orden de la experiencia, a la manera de los narradores tradicionales [...]" (Peris, 2005: 325). En este mismo sentido, Barros observa:

Desde el punto de vista formal, Sacco repite las técnicas propias de la literatura de testimonio, subgénero nacido en América Latina en la década de los sesenta como vehículo de la ideología izquierdista para denunciar las violaciones de los derechos humanos provocados por las dictaduras militares... (Barros, 2016).

Esta idea del silencio elocuente la podemos ejemplificar con la superviñeta que, a nuestro modo de ver, es una de las más estremecedoras de todo el texto. En ella observamos en la profunda oscuridad de la noche a los familiares de los masacrados buscando a tientas a sus deudos para darles sepultura (Sacco, 2012: 348-349). La escena muestra la debacle, un hecho incomprensible que define al acontecimiento como una ruptura del tiempo y una desarticulación del espacio. Los deudos están en el desamparo más despiadado, sin ninguna dirección deambulan por el desierto, sobre el vacío abierto por la tierra baldía. Niños, adultos, ancianos, finalmente, representan ahí a la humanidad toda. No es azaroso que Sacco (autor real) haya dejado muda esta viñeta, precisamente para hacerla hablar, para que la elocuencia del silencio testimonie con detalles los contornos incomprensibles del horror y el dolor. A través de la inquietud de la mudez, el lector puede comprender el sufrimiento y padecer junto a los dañados.

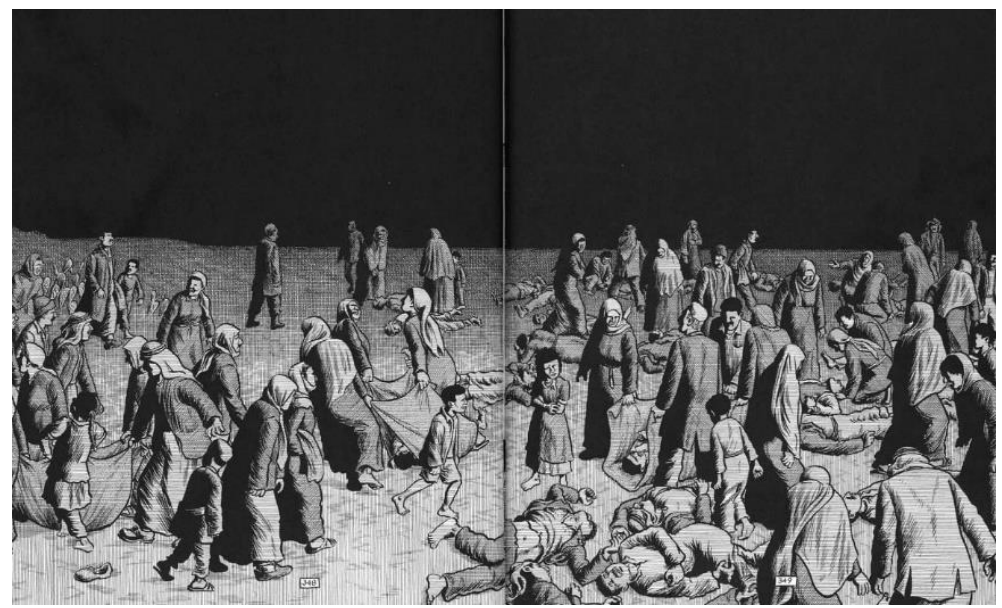

Ilustración 23 (Sacco, 2012: 348-349). 


\section{Anacronías: la imagen-combativa y la imagen-aura en Notas al pie de Gaza}

El análisis que realizaremos a continuación se sostiene en los planteamientos de Georges Didi-Huberman en Ante el tiempo (2011), libro del cual hemos recogido dos conceptos operativos que nos ayudan en nuestro propósito: los de la imagen-combate y la imagen-aura; ambos contenidos en el capítulo "Modernidad del anacronismo". Asimismo, la noción de anacronismo la incorporamos de forma específica para analizar las imágenes propuestas por Sacco en Notas al pie de Gaza.

Al especular sobre la historia, Didi-Huberman recoge las reflexiones fundamentales que Benjamin plantea en relación al tiempo como una dialéctica de flujo alternativo y anacrónico, pues pretende que se entretejan temporalidades disímiles en la actuación histórica, de manera que ésta no se reduzca a pensar y conocer sólo datos positivos sobre un pasado objetivo ni que se observe alineado en proyecto universal. Al respecto, Fisgativa agrega:

Tal concepción de la temporalidad es considerada por Benjamin como la historia de los vencedores, su razón hecha historia, ante la cual ya se han sacrificado muchos. A contracorriente de la historia de los victoriosos, la apuesta consiste en hacer la historia de los vencidos, de los documentos de la barbarie en la cultura, que no está necesariamente encaminada a la libertad ni tiene una pretensión de universalidad, y que puede rememorar aquellos acontecimientos, ruinas y sacrificios que han tenido lugar en el altar de la historia universal (2013: 158).

El presente desde el cual se construyen las imágenes del pasado como montaje de hechos genera temporalidades divergentes, que producen una especie de recarga energética en la memoria. Los restos, las "notas al pie", las ruinas que no logran ser digeridas por la economía del progreso o no logran ser admitidas en la precisión de la Historia continua, son las chispas que encienden la memoria en la colisión anacrónica de imágenes combativas.

Entre estos fragmentos espaciales y temporales se produce la dinámica dialéctica que re-une presente con pasado y que, en las imágenes de la novela gráfica, se concreta con la elisión espacio-temporal de dos mundos en una distante cercanía: "La memoria introduce la discontinuidad y el anacronismo en la historia, no aportando datos documentales, sino mediante un ejercicio, un proceso que permite vislumbrar entre las ruinas aquellos detalles que se resisten a desaparecer sin ser rememorados" (Fisgativa, 2013: 161).

La dialéctica que abren las imágenes diacrónicas en Notas al pie de Gaza provoca una colisión. Este movimiento en la temporalidad, por una parte, rompe la linealidad y fijeza de los hechos, ingresando en la porosidad y provocando la irrupción de una nueva y actualizada experiencia del acontecimiento. Por otra, la es- 
trategia discursiva visual genera que el "anacronismo descomponga la noción clásica de historia de las formas... El anacronismo de una colisión donde el Otrora se encuentra interpretado y 'leído', es decir, puesto al día por la llegada de un Ahora resueltamente nuevo" (Didi-Huberman, 2011: 264-265); y es esta su concreción en cuanto imagen-combativa.

En este sentido, Didi-Huberman, refiriendo la noción de Carl Einstein respecto de la teoría e historia del arte, remite a la idea de visión, pero no en tanto facultad, sino en tanto exigencia y trabajo; rechazando lo visible, por cuanto ya es evidente; apelando y reivindicando a la oscilación de la visualidad en la relación con los objetos, a su dialéctica en movimiento que desafía el estado estático de los objetos; enfrentando tanto a lo artístico como a lo disciplinario. A este respecto, es esclarecedora la cita que abre el texto citando a Benjamin:

La manera por la que el pasado recibe la impresión de una actualidad más reciente está por la imagen en la cual se halla comprendido [...] y esta penetración dialéctica, esta capacidad de hacer presentes las correlaciones pausadas, es la prueba de verdad de la acción presente. Eso significa que ella enciende la mecha del explosivo que mora en lo que ha sido (Didi-Huberman, 2011: 3).

Las siguientes imágenes dan cuenta efectiva de la especulación teórica que hemos propuesto. Encontramos que, en su contenido, hay una forma específica y una dialéctica precisa que concretan la operación artística de Sacco, así como su compromiso ético con una obra que provoca las colisiones mencionadas por DidiHuberman. En ambas viñetas podemos observar la apertura anacrónica, su dialéctica ante el tiempo y el espacio provocando un roce, una colisión que abre del acontecimiento su imposible histórico, su indecibilidad verbal. indecibilidad verbal. La imagen combativa se presenta en la manera que disloca la temporalidad fija, desafiando entonces a la Historia que lateraliza, margina, baja al pie o simplemente borra su contenido acontecido de las páginas oficiales. Las imágenes tienen la capacidad de restaurar del aura extraviada la temporalidad del acontecimiento. Al decir de Didi-Huberman, nos sitúan con y ante el tiempo del acontecimiento, hurgando en la experiencia desfasada y desplazada. A su vez, activan la parte crítica y actualizada de su propia historicidad. En tal sentido, el olvido huye ante la activación de la dualidad sustanciada.

Como podemos observar, las imágenes del pasado remiten a la era del tiempo detenido, al de los muertos, a la interrupción temporal del niño absorto frente a la experiencia de la muerte multiplicada a los pies del castillo o al paso humano de los niños y el anciano que, juntos, comparten un espacio cuya temporalidad también es anacrónica. En simultáneo, pasamos al presente del movimiento mecánico, al de los automóviles, la bicicleta, los medios de transporte simbólicos del progreso que, con su vertiginosidad, barren en el espacio y borran en el tiempo 
los acontecimientos. Contra ello, entonces, aparece la imagen combativa para colarse por los poros de la solidez histórica, para erosionar y tensionar la línea recta del historicismo. De la misma manera, esta imagen-combativa llama a la imagenaura, cuya chispa enciende la oscuridad impenetrable del acontecimiento, ilumina la opacidad del supuesto progreso y logra licuar la solidez del olvido colmándolo con una nueva mirada, con una nueva visión crítica y reconstructiva.
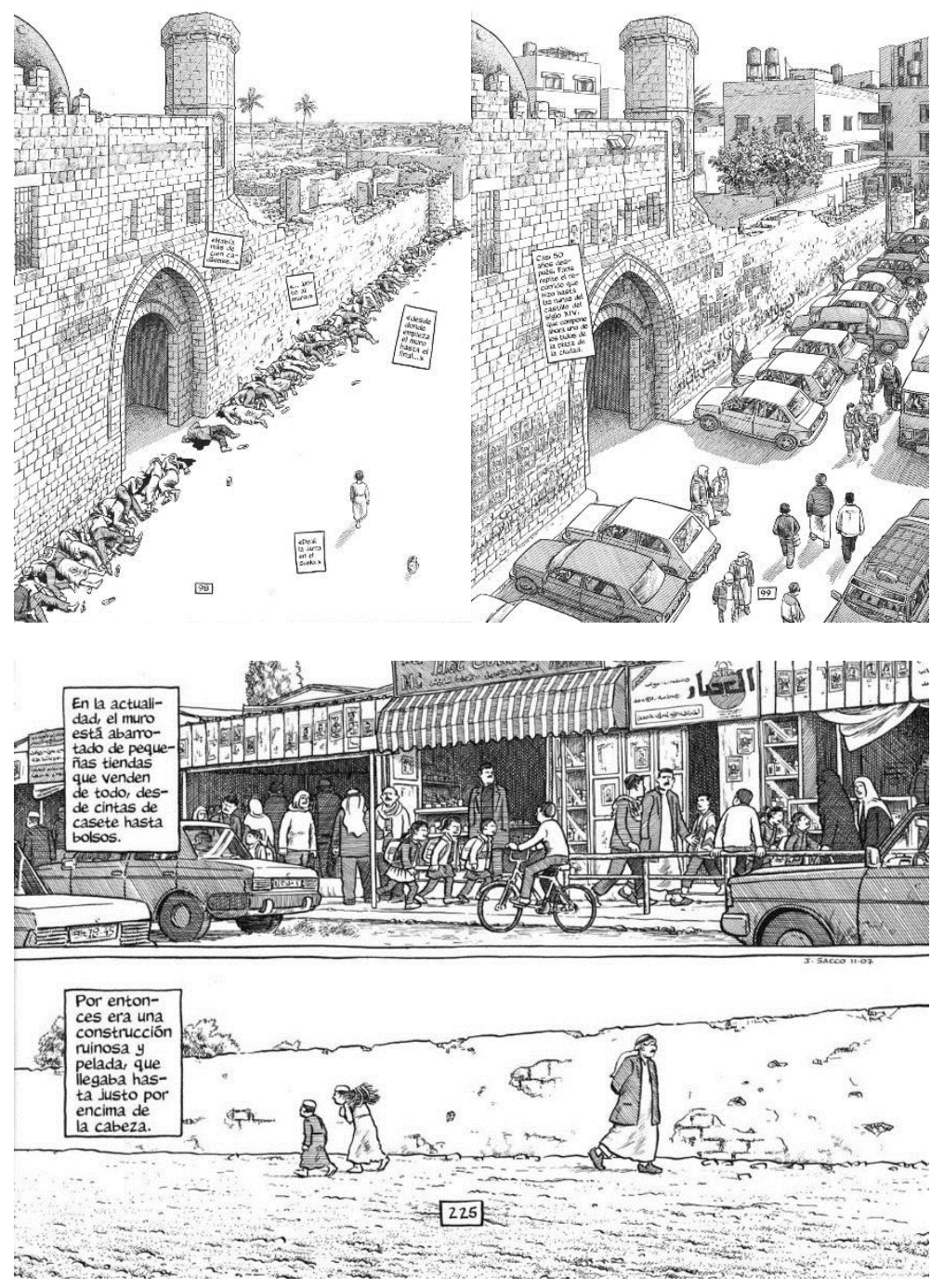

Ilustraciones 14 y 15 (Sacco, 2012: 98-99 y 225). 
Para finalizar la parte analítica y teórica de nuestro trabajo, comentaremos el singular alcance del último capítulo de Notas al pie de Gaza, "Sea Street", enlazándolo con una cita de Didi-Huberman que logra conceptualizar la materialización simbólica de las secuencias y las viñetas. El capítulo funciona de diversas formas. Primeramente, en su cometido formal en tanto cierre y conclusión, "Hemos acabado nuestro relato de 1956", dice el narrador en la nota que abre las escenas. Pero también nos muestra a un Sacco personaje con cierta nostalgia y agotado, no se sabe muy bien si por la empresa en sí o por las cargas transferenciales de los testimonios. Lo que sí queda más claro es su tenor de despedida:

Quizá había más hechos por destapar y más testimonios que oír, pero hemos llegado al punto de los rendimientos decrecientes, así que lo dejamos correr y que el resto caiga en el olvido... Saldremos de Rafah hacia Kahn Younis y después pasaremos el control de Abu Houli... Mañana estaré en Jerusalén y en Europa en pocos días (Sacco, 2012: 382).

El personaje Sacco repasa y mira el transcurrir de Sea Street reflexionando y evaluando las actividades, las rutinas metodológicas de su investigación. Mientras va ensimismado en el taxi, ocurre la activación anamnética y en esto recuerda la entrevista en particular que sostuvo con Abu Juhish, el anciano ya enfermo y quien fuera un superviviente de la matanza en la escuela de Rafah.
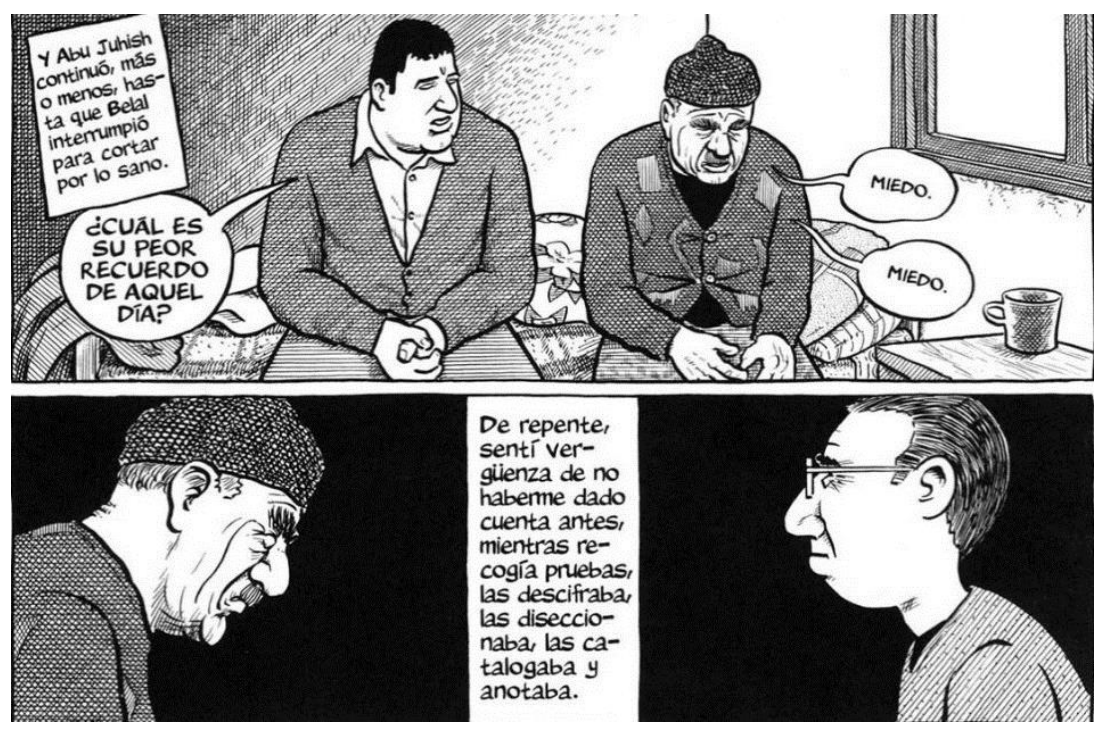

De repente, sentí vergilenza de no haberme dado cuenta antes, mientras recogía pruebas, las descifraba, las diseccionaba, las catalogaba y anotaba.

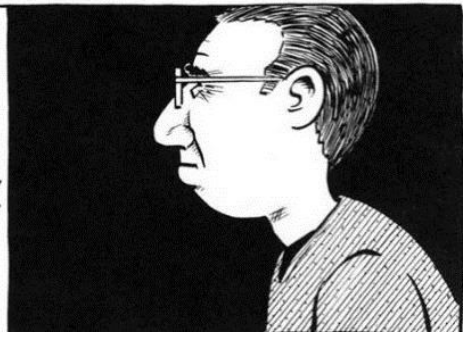

Ilustración 36 (Sacco, 2012: 384). 


\section{En palabras de Didi-Huberman:}

Lo real nunca deja de "quemar la imagen". La continua rememoración no cesa de darse como la "reliquia secularizada". Y si el silencio aparece como una cualidad fundamentalmente aurática [...] el hombre moderno, incluso posmoderno, el hombre de "la reproductibilidad técnica", en medio del ruidoso laberinto de las mediaciones, de las informaciones, de las reproducciones, debe algunas veces hacer silencio, y sufrir la inquietante de lo que le vuelve como aura, como aparición alterante (2011: 347-349).

La viñeta anterior comporta todo aquello referido en la cita, pues Joe Sacco personaje y Joe Sacco artista representan a ese hombre postmoderno, a ese hombre de la reproductibilidad técnica (que paradójica e inevitablemente concretamos en cada imagen que de la misma obra extraemos, cortando y pegando para hablar de ella misma). Entre todo ese ruido salvajemente maquinado, en el caos de la ciudad bajo amenaza permanente, donde la excepción es el estado habitual, lo vemos ahí en la omnipotencia de un auto Mercedes-Benz, representado en la imagen aurática que relampaguea en su memoria, en la reflexión sobre el otro, pensando y recordando su cara de "vergüenza", pero más bien en su actitud de comprensión con el anciano superviviente. Sacco, en el umbral donde la imagen-combativa permite la elisión del tiempo, en el ir-venir del automóvil y del jeep. El pensamiento cruza las puertas de ese acceso que sólo puede abrir la reflexión, ante la cual la memoria se sitúa móvil entre la división imaginaria del espacio temporal donde nada más pronuncia finalmente su silencio.

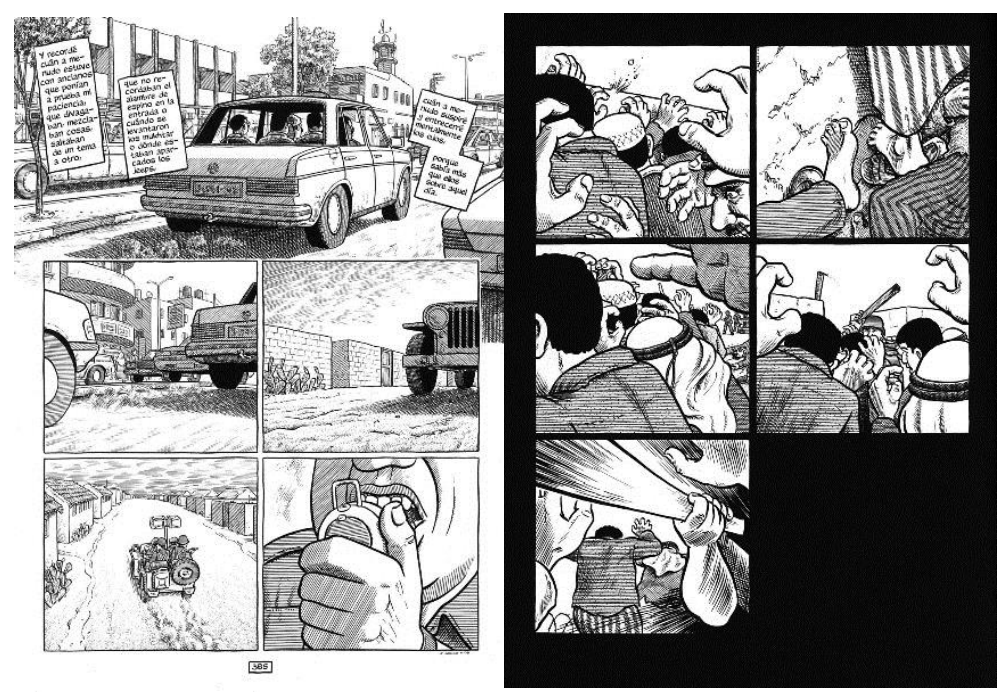

Ilustraciones 11 y 12 (Sacco, 2012:385-388). 
Juan Manuel Mancilla. Notas a pie de Gaza, de Joe Sacco: el anacronismo como posibilidad...

\section{Comentarios finales}

En esta parte, en medio de la era de los mass media, en la vertiginosa saturación informática aludida por Zygmunt Bauman y la liquidez inmediata que escurre y se resiste a solidificación, es pertinente retomar la concepción de la literatura dada por Jean-Paul Sartre y Simone de Beauvoir, en relación a que guardaría una cualidad distintiva dada por su capacidad de singularizar y especificar la experiencia humana. En este sentido, el lenguaje es opacidad, pero es a la vez medio y vaso comunicante entre las singularidades destotalizadas de la condición humana. Del mismo modo, es también válida la diferencia radical que establecen los filósofos franceses en cuanto a que la literatura se distancia de una teleología meramente informativa, logrando desplegar la diferencia en medio de la homogénea hegemonía (de textos):

Y es aquí donde la literatura encuentra su justificación y su sentido... no somos mónadas; cada situación está abierta para la otras, y está abierta para el mundo... Podemos comunicarnos a través de ese mundo que es una totalidad, aunque destotalizada, de ese mundo que existe para nosotros (Beauvoir, 1966: 70).

Actualizando el campo de interrogación abierto por los franceses sobre el sentido de la literatura, en las imágenes de la novela gráfica de Sacco las ideas expresadas en torno a la funcionalidad de la creación artística contemporánea encuentran superficie. En el texto, es posible ver plasmadas las cualidades de la literatura aludidas por Sartre y de Beauvoir en Para qué sirve la literatura, donde la totalidad destotalizada del mundo (de Gaza) se abre y se debate sobre el decir ético a través del discurso artístico. En este sentido, la concretización hecha por Sacco nos desafía respecto de la toma de posición frente al conflicto árabe-israelí, emplazándonos como lectores hacia el compromiso ético y estético en aquella "conciencia del lector" que postulaba Sartre, en tanto que "toda obra literaria es un Ilamamiento. Escribir es pedir al lector que haga pasar la existencia objetiva la revelación que yo he emprendido por medio del lenguaje" (Sartre, 1967: 71).

El arte que ofrece Sacco en Notas al pie de Gaza es aquel que puede ubicarse dentro de la postura crítica, un arte gráfico que viene a restituir la mirada sobre las acciones humanas. A nuestro juicio, su propuesta es satisfactoria. El montaje de imágenes se organiza en torno a una finalidad de carácter simbólico en donde los contrarios, los impares binarios, como más arriba les hemos llamado, colisionan entre sí, sacando aquellas chispas que alumbran la oscuridad inaccesible del acontecimiento que narra. Llevados los elementos teóricos al plano analítico, efectivamente vemos que, en el texto, estos son explorados notablemente, no sólo por su demostración en cuanto al dominio técnico, sino más bien por cómo logra ponerlos en funcionamiento de acuerdo al contenido que el mensaje va 
transmitiendo en el proceso comunicativo entre texto y lector. Su estrategia compositiva no decae; la conciencia escritural y gráfica de Sacco destaca no sólo por su calidad y cualidades técnicas, sino, además, por su capacidad irruptora, por su despliegue de direcciones en busca de un sentido, el cual, creemos, apunta hacia la denuncia y la crítica ante las injusticias humanas, lo que, a fin de cuentas, es lo que juzgamos más destacado en su obra.

Finalmente, hemos intentado abrir el texto y desplegar algunos de sus múltiples aspectos problemáticos a la luz de conceptos teóricos que nos brindaron apoyo y estímulo para adentrarnos en la materia, intentado abordar la cuestión sobre el cuestionamiento a la Historia, el rol crítico de las imágenes y del arte. Pensamos que cada uno de los temas podría abordarse en sí de manera más específica, es decir, aislando los testimonios de las experiencias límites que la novela trata o el trauma que enfrentan sus personajes. Por supuesto, sólo hemos abordado de forma parcial y con carácter ensayístico las ideas expuestas. La respuesta a nuestra hipótesis en ningún caso pretende ser definitiva y, por el contrario, es una primera estación para el recorrido amplio y lento que la lectura de la novela Notas al pie de Gaza demanda hacer en relación a la problemática expuesta, que, finalmente, es la de confrontar al ser humano mismo con su dimensión ética en la cita con la postmodernidad.

\section{Referencias}

Bal, Mieke (1990). Teoría de la narrativa: Una introducción a la narratología. Trad. Javier Franco. Madrid: Cátedra.

Barrero, Manuel (2013). La novela gráfica: perversión genérica de una etiqueta editorial. José Manuel. ed. La novela gráfica. Poéticas y modelos narrativos. Madrid: Arco/Libros. 191-230.

Barros, Diego (2016). La paz no va pagarme el alquiler. Joe Sacco. Jot Down. Recuperado el 22 de junio de 2016 de http://www.jotdown.es/2012/11/la-paz-no-va-a-pagarmeel-alquiler-joe-sacco/

Bauman, Zygmunt (2015). Tiempos líquidos. Vivir en una época de incertidumbre. Buenos Aires: Tusquets.

Beauvoir, Simone de (1966). Para qué sirve la literatura. Pról. Noé Jitrik. Buenos Aires: Proteo.

Campbell, Eddie (2013). La cultura del comic book frente a la cultura de la novela gráfica. Trabado, José Manuel, ed. La novela gráfica. Poéticas y modelos narrativos. Madrid: Arco/Libros. 231-239.

Díaz de Guereñu, Juan Manuel (2014). Historietas de la guerra de Bosnia: testimonio y género. Hacia un cómic de auto. Bilbao: Universidad de Deusto. 59-102. 
Juan Manuel Mancilla. Notas a pie de Gaza, de Joe Sacco: el anacronismo como posibilidad...

Didi-Huberman, Georges (2011). Ante el tiempo: Historia del arte y anacronismo de las imágenes. Trad. Antonio Oviedo. Argentina: Adriana Hidalgo.

Eisner, Will (2007). El cómic y el arte secuencial. Barcelona: Norma.

Fisgativa, Carlos (2013). Imágenes dialécticas y anacronismo en la historia del arte (según Georges Didi-Huberman). Filosofía UIS. 12(1). Bucaramanga: Universidad Industrial de Santander. 155-180.

Folman, Ari, Polonski, D. (2014). Vals con Bashir. Trad. Isabel Margelí. Barcelona: Salamandra.

Giménez, Carlos. (2007). Malos tiempos. Barcelona: Ediciones Glénat.

LaCapra, Dominik (2006). Historia en tránsito: experiencia, identidad, teoría crítica. Buenos Aires: FCE.

Peris, Jaume (2005). La imposible voz: Memoria y representación de los campos de concentración en Chile: la posición del testigo. Santiago: Cuarto Propio.

Prieto, Mónica (2016). Crónicas desde Oriente Próximo. Notas al pie de página en Gaza, mucho más que un comic. El mundo [Blog]. Recuperado el 15 de Julio de 2016 de http://www.elmundo.es/blogs/elmundo/orienteproximo/2010/02/01/notas-alpie-de-pagina-en-gaza-mucho-mas.html.

Sartre, Jean Paul (1967). ¿Qué es la literatura? Trad. Aurora Bernárdez. Buenos Aires: Losada.

Sacco, Joe (2012). Notas al pie de Gaza. Trad. Marc Viaplana. Barcelona: Penguin Random House.

(2004). Palestina en la franja de Gaza. Trad. Roberto Rodríguez. Barcelona: Planeta de Agostini.

Spiegelman, Art. (2004) Sin la sombra de las torres. Adaptación gráfica Martín Garcés. Barcelona: Norma.

White, Hayden (1992). El contenido de la forma: Narrativa, discurso y representación histórica. Barcelona: Paidós.

Worden, Daniel (2015). The Comics of Joe Sacco. Journalism in a visual World. Jackson, MS: The University Press of Mississippi. 